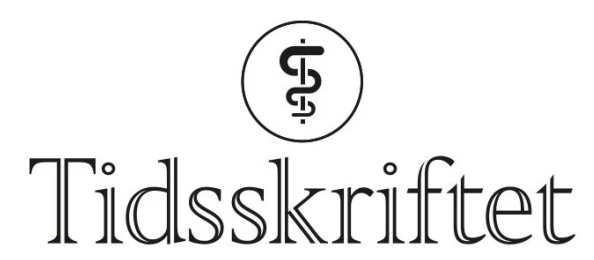

DEN NORSKE LEGEFORENING

\title{
Pasient, du lyver!
}

\author{
LEGELIVET
}

\section{FREDERIK EMIL JUUL}

fejuul.medisin@gmail.com

Frederik Emil Juul er lege og forsker i forskningsgruppen Klinisk effektforskning ved Oslo universitetssykehus, Rikshospitalet.

\section{Noen pasienter velger å tilpasse sin egen sykehistorie.}

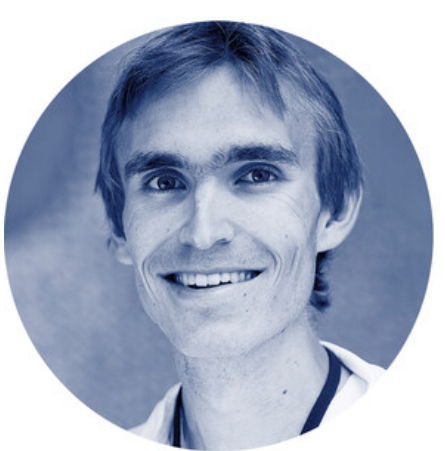

Foto: Jon Olav Nesvold

Overfor enkelte pasienter har jeg tatt meg selv i å tenke "pasient, du lyver!», selv om jeg neppe har like rettmessig grunn til en slik anklage som mor Åse i Peer Gynt. Den noe urovekkende tanken kommer for eksempel i møte med en pasient som svarer på om medisinene er tatt som forskrevet, eller som hevder å ikke ha røykt på flere år selv om gullige fingre og sterk røyklukt antyder noe annet. Om min indre anklage er rettmessig eller ikke, vil sannsynligvis variere, men studier har vist at overraskende mange pasienter holder tilbake informasjon, fordreier egen sykehistorie eller rent frem lyver for legen (1). Hva er det som får pasientene til å tilpasse egen sykehistorie eller symptomer når de snakker med legen?

Feilsiteringer og diagnoser i pasientjournalen eller misforståelser hos pasienten eller legen er selvsagt mulige forklaringer, men i flere tilfeller tror jeg det er en mer eller mindre bevisst handling fra pasientens side. For eksempel kan pasienten underslå hvor mye alkohol hen drikker, kanskje fordi hen synes det er flaut eller ønsker å unngå legens moralske dom. Andre kan overdrive hvor mye de trener eller antallet grønnsaker de spiser for å fremstå som «flinke». I lys av feriebeskrivelsene og bildene som deles i sosiale medier, er ikke dette unikt for kommunikasjonen mellom lege og pasient. 
Sosiale medier og internett har også gjort det lettere for pasienter å finne informasjon om sykdommer og hvilke symptomer legen spør etter for å stille en diagnose. Diagnosen kan i neste rekke føre til en utredning eller behandling som pasienten ønsker, og dette ønsket påvirker hvordan pasienten svarer på legens spørsmål. Tilsvarende, i forskningens verden, kan potensielle studiedeltakere velge å svare slik de tror de skal for å oppfylle kriteriene for å være med i studien.

\section{«Hva er det som får pasientene til å tilpasse egen sykehistorie eller symptomer når de snakker med legen?»}

I andre tilfeller tilpasser pasientene sin egen sykehistorie og symptomer for å unngå en diagnose, behandling eller anbefaling. Et småhumoristisk eksempel var en tydelig treningsivrig person som kom haltende til meg med ønske om smertestillende tabletter samtidig som han presiserte at smertene ikke var så ille. Senere i samtalen kom det fram at pasienten skulle løpe maraton noen dager senere og derfor ikke ville høre noen anbefaling fra legen om å hvile. Pasienten ville neppe ha dødd om denne informasjonen forble skjult for legen, men dessverre kan pasienter velge å holde tilbake opplysninger som de har lest seg til at kan tyde på en alvorlig, dødelig sykdom.

Samtidig skal man ikke glemme at de fleste pasientene viser oss stor tillit i hva de forteller fra privatlivet, som hvordan avførings- eller seksualatferden har vært den siste tiden. Mange synes det er flaut eller tabu å snakke om slike tema, og legen er kanskje den første og eneste som får vite hva pasienten opplever. For å unngå at andre ved legekontoret får kjennskap til det pinlige pasienten vil snakke med legen om, er det noen som bestiller time for relativt trivielle plager, som en ukomplisert urinveisinfeksjon. I beste fall sier pasienten hva hen egentlig kommer for ved begynnelsen av konsultasjonen. Andre virker å vente til senere i konsultasjonen eller like før hen skal til å forlate kontoret - det såkalte dørklinkefenomenet.

\section{«Enkelte elementer som kjønn og alder kan jeg ikke gjøre så mye med, men hvordan jeg kommuniserer og inviterer til tillit, er det fullt mulig å endre»}

I noen tilfeller virker det som om pasienten aldri kommer over terskelen for å snakke om det som virkelig plager eller bekymrer hen. For eksempel hadde jeg en kvinnelig pasient som i konsultasjonen aldri helt uttrykte hvorfor hun hadde bestilt legetime. Hun fortalte at kroppen fungerte som den skulle og hun syntes hverdagen var finfin. I ettertid har jeg lurt på om det var noe med meg som stoppet pasienten fra å dele hele sykehistorien. Enkelte elementer som kjønn og alder kan jeg ikke gjøre så mye med, men hvordan jeg kommuniserer og inviterer til tillit, er det fullt mulig å endre.

Her ligger kanskje noe av grunnen til at enkelte pasienter fordreier eller lyver om egen sykehistorie: De mangler tillit til at legen ikke vil være dømmende overfor pasientens atferd eller empatisk overfor pinlige symptomer. Andre kan mangle tillit til at legen vil identifisere alvorlig sykdom eller tilby dem riktig behandling for sine plager.

Kanskje jeg bør tenke over hvorfor pasienten skal ha tillit til meg når jeg ikke har tillit til hen neste gang jeg tenker "pasient, du lyver!».

\section{LITTERATUR}

1. Levy AG, Scherer AM, Zikmund-Fisher BJ et al. Prevalence of and factors associated with patient nondisclosure of medically relevant information to clinicians. JAMA Netw Open 2018; 1: e185293. [PubMed][CrossRef] 
Publisert: 27. august 2021. Tidsskr Nor Legeforen. DOI:10.4045/tidsskr.21.0555

(C) Tidsskrift for Den norske legeforening 2023. Lastet ned fra tidsskriftet.no 26. april 2023. 